\title{
THE GENERAL PRACTITIONER AND THE SURGEON: STEREOTYPES AND MEDICAL SPECIALTIES
}

\author{
Patrícia Lacerda Bellodi
}

BELLODI PL - The general practitioner and the surgeon: stereotypes and medical specialties. Rev. Hosp. Clín. Fac. Med. S. Paulo 59(1):15-24, 2004.

OBJECTIVE: To investigate and characterize the professional stereotypes associated with general medicine and surgery among Brazilian medical residents.

METHODS: A randomized sample of residents of the General Medicine and Surgery Residence Programs were interviewed and their perceptions and views of general and surgical doctors were compared.

RESULTS: The general practitioner was characterized by the residents in general to be principally a sensitive and concerned doctor with a close relationship with the patient; $(45 \%)$; calm, tranquil, and balanced (27\%); with intellectual skills (25\%); meticulous and attentive to details (23\%); slow to resolve problems and make decisions (22\%); and working more with probabilities and hypotheses (20\%). The surgeon was considered to be practical and objective (40\%); quickly resolving problems (35\%); technical with manual skills (23\%); omnipotent, arrogant, and domineering (23\%); anxious, stressed, nervous, and temperamental (23\%); and more decided, secure, and courageous (20\%). Only the residents of general medicine attributed the surgeon with less knowledge of medicine and only the surgeons attributed gender characteristics to their own specialty.

CONCLUSION: There was considerable similarity in the description of a typical general practitioner and surgeon among the residents in general, regardless of the specialty they had chosen. It was interesting to observe that these stereotypes persist despite the transformations in the history of medicine, i.e. the first physicians (especially regarding the valorization of knowledge) and the first surgeons, so-called "barber surgeons" in Brazil (associated with less knowledge and the performance of high-risk procedures).

\section{DESCRITORES: Career choice. Specialties, medical. Education, medical. Stereotypes, Brazil.}

There is a further challenge for the medical student at the end of the course of training - that is, the moment for the choice of specialty has arrived.

This choice demands that the student consider who he is, what he wants do, and where, how, and what role model to follow. He assesses the professional and personal models observed at school and especially the opinions - confirmed or refuted, explicit or presented in a subtle way and disguised - about each specialty and its area of performance.
It is in this context that the choice of a specialty is influenced by professional stereotypes.

The stereotypes are created by oversimplification and excessive categorizing of the so-called "social representations". These consist of a group of concepts, explanations, and affirmations that arise in daily life out of popular opinion, elaborated in an

From Hospital das Clínicas, Faculty of Medicine, University of São Paulo - São Paulo/SP, Brazil.

Received for publication on August 12, 2003. attempt to deal with and organize the aspects of reality that are continually being presented to a person ${ }^{1}$.

Those typical characteristics can be particularly important to some students who tend to evaluate the specialties in accordance with their perception of their own abilities, almost like a selfselection process.

In view of this, it becomes very important to better understand which are the abilities traditionally emphasized in these stereotypes, because those can be, in a certain way, factors of selection for the future professionals of each area ${ }^{2}$. 
Studies regarding the involvement of professional stereotypes in the choice of a medical specialty have shown that the ideas diffused remain stable throughout the course of training, having only variations in degree or emphasis along the succeeding years. They also show that the characterizations of each specialty remain the same regardless of the student's intention to enter or not enter that particular specialty ${ }^{3-4}$.

In general, the results of these studies $^{5-13}$ show that the general practitioner is considered to be a doctor who is deeply interested in intellectual questions and problems, intelligent, patient, friendly, with a pleasant personality and sensitive to a wide range of factors when he evaluates a general problem. General medicine is considered the widest of the specialties. It requires greater knowledge and a disposition for learning. However, the general practitioner is seen as poorly paid, subject to unsatisfactory work conditions, more unsatisfied with his work, and of low status. Women are more prone to chose general medicine as a specialty.

The surgeon, on the other hand, it is seen as a dominant and arrogant doctor, aggressive, energetic, and very concerned with his own prestige. He is seen as decisive, efficient, and a realist, but as an impersonal and autocratic person. Egocentric, he is more interested in rapid actions and immediate results than in interpersonal relationships. He works hard, expresses himself physically, is always in motion, and is incapable of relaxing. But he is satisfied and he has high status. Also seen as unsophisticated and somewhat cruel, he is oriented more toward things than toward people. Surgery is considered the specialty with the poorest doctor-patient relationship and is chosen more by men. Requiring less academic commitment, it is a field in which the specialist has to like to work more with his hands and to have the physical capacity to work long hours on his feet.

In Brazil, few studies have been done on the subject of the specialty stereotypes, but the results found here are not in disagreement with research done in other countries.

A study ${ }^{13}$ involving students in their last year in 8 medical schools verified a consensus in the perception of surgery as the specialty of greater prestige, both socially and within the medical group, and the least appropriate for women. General practice or internal medicine was seen as producing lower monetary income, little social prestige, but with high status (just below surgery) within the medical profession.

In other research ${ }^{14}$ in which 3 successive groups of first-year students were compared, there was considerable similarity between the students regarding the values attributed to the various specialties: the prestige associated with surgery and pediatrics; the monetary profitability of surgery and psychiatry; the doctor-patient relationship in psychiatry and general practice; the intraprofessional relationship between otorhinolaryngology/ophthalmology and pediatrics; the challenge to inteland pediatrics; and the possibility of controlling working hours in public health and psychiatry.

However, no survey had yet been done in Brazil exploring perceptions regarding medical specialties among residents or doctors with a longer period of time in professional service.

The continuation of studies into the question of professional stereotypes is very important because such lectual capacity in general practice

stereotypes have great influence not only in the choice but also in the conduct of medical practice. If a practice becomes ensnared in those rigid representations, it can be inappropriate for the needs of patients, of society, and of the doctors themselves.

\section{OBJECTIVE}

The objective of this study was to investigate the residents' views of professional stereotypes of general practitioners and surgeons and to discuss the results in relation to that diffused by popular opinion and found in the medical specialty choice literature.

\section{METHOD}

The participants were 60 residents in the first (R1) and second year (R2) of the Residence Programs in Surgery and General Medicine, the having the following distribution (Table 1):

The 2 groups were constituted through random selection attempting to compose a balanced sample of the genders. The composition of the residents' total population in the 2 specialties in the period of the collection of the data is presented below (Table 2).

In Brazil, regarding general medicine and surgery, the first 2 years of residence precede, for those who wish it, the subsequent choice of the subspecialty, a specific area of performance within their own specialty (for instance endocrinology in the general area, and plastic surgery in the surgical field).

Table 1 - Composition of the groups according to specialty, year of residence, and gender.

\begin{tabular}{ccccccc}
\hline \multirow{2}{*}{ SAMPLE } & \multicolumn{2}{c}{ General Practitioner } & \multicolumn{3}{c}{ Group } & \multicolumn{2}{c}{ Surgery Group } \\
& Male & Female & Total & Male & Female & Total \\
\hline R1 & 7 & 8 & 15 & 10 & 5 & 15 \\
R2 & 8 & 7 & 15 & 11 & 4 & 15 \\
\hline
\end{tabular}


Table 2 - Composition of the population according to specialty, year of residence, and gender in the moment of the study.

\begin{tabular}{ccccccc}
\hline Populatio Rasidents & \multicolumn{3}{c}{ General Practitioner } & \multicolumn{2}{c}{ Surgery } & \multirow{2}{*}{ FMUSP } \\
Male & Female & Total & Male & Female & Total \\
\hline R1 & 36 & 20 & 56 & 30 & 6 & 36 \\
R2 & 24 & 23 & 47 & 32 & 4 & 36 \\
\hline
\end{tabular}

The randomly selected residents who agreed to participation in the research were interviewed after having given both verbal and written consent. In this interview, the characteristics usually associated with the general practitioner and with the surgeon were investigated using the open questions: "How would you describe a general practitioner? How would you describe a surgeon?"

The classification of the answers given by the subjects and the establishment of frequencies were accomplished by the researcher herself and also by 2 other independent judges.

Analysis of the data and comparison of the frequencies was done using non-parametric statistical analyses with Mann Whitney U and chi-square tests, adopting a significance level of $p=0.05$.

\section{RESULTS}

In Table 3 and 4, the results shown are the qualities that each group and the residents as a whole attributed to the general practitioner and surgeon.

\section{The general practitioner}

The results relative to the general practitioner's stereotype show that a general practitioner is described by the residents in general mainly as:

- a doctor who is friendly, sensitive, and concerned with his patient $(45 \%)$

The surgeons $(23 \%)$ agreed with this characterization, but it was particularly the general residents $(67 \%)$ who characterized the general practitioner as such $(p=0.000)$.

"He has a very great interest in the patient. He is a doctor with heart, he is interested in the patient, he likes him, he doesn't do a consultation in 5 minutes, he is interested in the patient's life." Gen Med. female

- is calm, tranquil, stable, and balanced $(27 \%)$

"Calmer: about whatever comes, whatever goes on, whatever happens, for whatever reason something appeared... "Sur. male

- has intellectual abilities (25\%)

"He is a thinker. He thinks, he likes to think, the rest is not typical." Sur. male

- is meticulous with details (23\%)

"He likes conversation a lot, to get many details from the patient, to cover everything... "Sur. male

- is irresolute and slow in making decisions $(22 \%)$

“'He knows everything and doesn't resolve anything, as goes the joke... “ Gen Med. female

- works more with probabilities and hypotheses than with certainty (20\%)

"Abstract thought, they suffer often because of the lack of objectivity, there are so many options, it could be that..., but... "Sur. male

- has a global view of the patient, but pays attention also to subjective aspects (18\%)

While 1 surgery resident (3\%) agreed with this characterization in the description of general practitioners, a third of the general residents $(33 \%)$ affirmed that the general practitioner takes a global view of the pa- tient $(p=0.003)$ :

"He knows that a lot of people don't have organic problems and that he needs to have 'feeling' to sense the whole being and to know how to deal with those problems..." Gen Med. male

Some surgery residents (13\%) disagreed in a statistically significant way ( $p=0.040)$ with that characterization of the general practitioner, saying that, in fact, he is interested more in the discussion of the case than the patient. They say then that the general practitioner:

". . . wants to study the disease. Later he sees if the treatment worked. They extrapolate too much: they focus on other things and they forget about the patient..." Sur. male

- is more studious (18\%) and has more knowledge (17\%).

"He has a general 'bibliographical review' in mind, he is a 'walking MEDLINE'... " Gen Med. female

- is theoretical and not very objective (17\%)

Only 2 residents of general medicine attributed that characteristic to the doctors of their own specialty.

However, residents of surgery $(27 \%)$ point out these characteristics in a significant degree $(p=0.039)$, saying that:

"They know a lot of theory, but in practice they don't always succeed in solving the problems... "Sur. Female

- is easygoing and slow in the execution of tasks (13\%)

"He takes a long time examining and listening to the patient... " Gen Med. female

- is careful and deliberate (13\%)

"When confronted by a situation, he analyzes it, he reads up on it, discusses it... " Gen Med. female

Besides these statistically significant differences of opinion in the most frequent categories, other statistical differences were also verified in the general practitioner's characterization, as follows: 
Table 3 - The General Practitioner: in the opinion of the general medicine and surgery groups and residents in general.

\begin{tabular}{|c|c|c|c|c|}
\hline \multirow[b]{2}{*}{ CATEGORIES } & \multirow[b]{2}{*}{ STEREOTYPE } & \multicolumn{3}{|c|}{ The General Practioner } \\
\hline & & $\begin{array}{c}\text { Gen Med } \\
(\mathrm{n}=30) \\
\%\end{array}$ & $\begin{array}{c}\text { Surgery } \\
(\mathrm{n}=30) \\
\%\end{array}$ & $\begin{array}{c}\text { Total } \\
(\mathrm{n}=60) \\
\%\end{array}$ \\
\hline \multirow[t]{3}{*}{ Type of doctor } & Complete doctor $* *$ & 3 & & 2 \\
\hline & Limited doctor & 3 & 13 & 8 \\
\hline & Necessary doctor & & 13 & 7 \\
\hline \multirow[t]{4}{*}{ Vison of patient } & Global vision of patient / Atention also to subjective aspects * & 33 & 3 & 18 \\
\hline & Partial vision of patient / Atention only to organic aspects & & & \\
\hline & More interested in discussing the case than in the patient $*$ & & 13 & 7 \\
\hline & More interested in the surgical act than in the patient & & & \\
\hline \multirow[t]{2}{*}{ Skills } & Intellectual skills / Reflexive & 30 & 20 & 25 \\
\hline & Manual dexterity / Technical & & & \\
\hline \multirow[t]{6}{*}{ Type of thinker } & Attention to detail / Meticulous / Observant & 23 & 23 & 23 \\
\hline & Simplistic / No attention to details & & & \\
\hline & Abstract / Deals with uncertainty, ideas, hypotheses and probabilities & 20 & 20 & 20 \\
\hline & Concrete / Works with the palpable, material, sensory and visual & & & \\
\hline & Logical & 3 & & 2 \\
\hline & "Open mind" & 10 & & 5 \\
\hline \multirow{9}{*}{$\begin{array}{l}\text { Relationship with } \\
\text { knowledge }\end{array}$} & Scientist / Valorizes research & 3 & 7 & 5 \\
\hline & Empirical / Values experience & & 3 & 2 \\
\hline & Greater knowledge & 20 & 13 & 17 \\
\hline & Less knowledge $* *$ & & & \\
\hline & Reasonable knowledge & 3 & & 2 \\
\hline & More studious & 27 & 10 & 18 \\
\hline & Less studious & & & \\
\hline & Intelligent & 3 & & 2 \\
\hline & "Mulish" & & & \\
\hline \multirow{18}{*}{$\begin{array}{l}\text { Type of intervention } \\
\text { and problem solving }\end{array}$} & Theoretical / Not very objective * & 7 & 27 & 17 \\
\hline & Practical / Objective & & & \\
\hline & Expectant & & 3 & 2 \\
\hline & Interventionist & & & \\
\hline & Easy going / slow to realize tasks & 10 & 17 & 13 \\
\hline & Active / Dynamic in tasks & & & \\
\hline & Does not resolve / Slow decision maker & 13 & 30 & 22 \\
\hline & Resolves / Rapid decision maker & & & \\
\hline & Knows how and when to refer & 7 & & 3 \\
\hline & Refers too often & & 7 & 3 \\
\hline & Decided / Secure/ Courageous & 3 & 3 & 3 \\
\hline & Undecisive / Insecure / Fearful & 7 & 7 & 7 \\
\hline & Precipitated / Impulsive & & & \\
\hline & Prudent / Judicious & 13 & 13 & 13 \\
\hline & Good sense & 3 & & 2 \\
\hline & Lack of good sense & & 3 & 2 \\
\hline & Less responsible for results & & 3 & 2 \\
\hline & Greater responsibility for results & & & \\
\hline \multirow[t]{4}{*}{ Relationship with team } & Leadership capacity / Valorizes hierarchy & & 3 & 2 \\
\hline & Submissive / Dependent on professor & & & \\
\hline & Demanding / Intolerant of other workers' performance & & & \\
\hline & Flexible / Tolerant of other workers' performance & 7 & 3 & 5 \\
\hline \multirow[t]{3}{*}{ Relationship with patient } & $\begin{array}{l}\text { Close / Sensitive / concerned } * \\
\text { Distant / Insensitive / Cold } * *\end{array}$ & 67 & 23 & 45 \\
\hline & Nonaggressive & & 3 & 2 \\
\hline & Aggressive / Invasive & & & \\
\hline
\end{tabular}


Table 3 - continuation

\begin{tabular}{|c|c|c|c|c|}
\hline \multirow[b]{2}{*}{ CATEGORIES } & \multirow[b]{2}{*}{ STEREOTYPE } & \multicolumn{3}{|c|}{ The General Practioner } \\
\hline & & $\begin{array}{c}\text { Gen Med } \\
(\mathrm{n}=30) \\
\%\end{array}$ & $\begin{array}{c}\text { Surgery } \\
(\mathrm{n}=30) \\
\%\end{array}$ & $\begin{array}{c}\text { Total } \\
(\mathrm{n}=60) \\
\%\end{array}$ \\
\hline \multirow{8}{*}{$\begin{array}{l}\text { Relationship with } \\
\text { profession }\end{array}$} & Does not enjoy work / Disheartened & & 3 & 2 \\
\hline & Enjoys work / Well-disposed $*$ & 13 & & 7 \\
\hline & Does not like stressful situations & & 3 & 2 \\
\hline & Enjoys stressful situations & & & \\
\hline & Idealist / Unselfish / Altruist & 10 & 3 & 7 \\
\hline & Dissatisfied with remuneration / Stressed with work conditions $*$ & 13 & & 7 \\
\hline & Valorizes financial aspect & & & \\
\hline & Competitive / Ambitious & & & \\
\hline \multirow[t]{14}{*}{ Personality Characteristics } & Optimist & & & \\
\hline & Pessimist & & 3 & 2 \\
\hline & Modest / Less imposing & & 7 & 3 \\
\hline & Omnipotent / Arrogant / Prepotent & & & \\
\hline & Seductive & & & \\
\hline & Educated & 3 & & 2 \\
\hline & Rude / Bad-mannered ** & & 3 & 2 \\
\hline & Tranquil / Calm / Stable / Balanced & 33 & 20 & 27 \\
\hline & Anxious / Stressed / Nervous / Temperamental & & & \\
\hline & Introverted / Timid & & 3 & 2 \\
\hline & Extroverted / Comunicative & 3 & & 2 \\
\hline & Good-humored & 3 & & 2 \\
\hline & Tiresome / Obstinate/ Stubborn & 13 & 3 & 8 \\
\hline & Dissociated (both in and out of work environment) & & & \\
\hline \multirow{4}{*}{$\begin{array}{l}\text { Characteristics of } \\
\text { appearance }\end{array}$} & Short / Fat / Glutton & 3 & & 2 \\
\hline & Tall / Thin / large / Leptosomal & & & \\
\hline & Relaxed / Dresses informally & 3 & 3 & 3 \\
\hline & Vain / Dresses formally & & & \\
\hline \multirow[t]{4}{*}{ Characteristics of gender } & Male sex: inherent to masculine personality & & & \\
\hline & Female sex: ruder and more stressed than men & & & \\
\hline & Female sex: hard to reconcile professional and family life & & & \\
\hline & Female sex: discriminated $* *$ & & & \\
\hline
\end{tabular}

Non-parametric: Mann Whitney U test $(\mathrm{p}<0.05)$. Note: Categories are not mutually exclusive

* Statistically significant difference between the specialties for the General Medicine group

** Statistically significant difference between the specialties for the Surgery group

- a necessary doctor $(p=0.040)$

A few residents of surgery (13\%) considered the general practitioner to be necessary, saying:

"He's a character that is pretty scattered, but they are necessary. I love that, it is fundamental... "Sur. male

- a doctor who likes what he does very much $(p=0.040)$, but is dissatisfied with the remuneration and work conditions $(p=0.040)$

Only the residents of the general medicine group (13\%) highlighted these aspects, saying of the general practitioner:

"He has to be strong to give serv- ice and yet he is poor... "Gen Med. male

\section{The Surgeon}

The surgeon is described by the residents as a whole mainly as:

- a practical and objective doctor (40\%)

"An objective person that tries to go directly to the heart of the matter... "Sur. male

- resolute and quick in making decisions $(35 \%)$

"The surgeon decides, he does not delay: in one day they hospitalize the patient, he operates, if everything goes well, the patient is cured." Gen Med. male

- has manual abilities and works essentially as a technician (23\%)

"Surgery, if you don't feel with your hands, you don't learn" Sur. male

- is omnipotent, arrogant, and dominating $(23 \%)$

"Owner of the situation, arrogant... not only on the professional level, but also in the personal, it crosses over...

"Sur. male

- is anxious, stressed, nervous, temperamental $(23 \%)$

"His lifestyle involves a lot of stress and is very exacting... "Sur. male - is decisive, self-assured, and cou- 
Table 4 - The Surgeon: in the opinion of the general medicine and surgery groups and residents in general.

\begin{tabular}{|c|c|c|c|c|}
\hline \multirow[b]{2}{*}{ CATEGORIES } & \multirow[b]{2}{*}{ STEREOTYPE } & \multicolumn{3}{|c|}{ The Surgeon } \\
\hline & & $\begin{array}{c}\text { Gen Med } \\
(\mathrm{n}=30) \\
\%\end{array}$ & $\begin{array}{c}\text { Surgery } \\
(\mathrm{n}=30) \\
\%\end{array}$ & $\begin{array}{c}\text { Total } \\
(\mathrm{n}=30) \\
\%\end{array}$ \\
\hline \multirow[t]{3}{*}{ Type of doctor } & Complete doctor $* *$ & & 20 & 10 \\
\hline & Limited doctor & 10 & 3 & 7 \\
\hline & Necessary doctor & 3 & & 2 \\
\hline \multirow[t]{4}{*}{ Vison of patient } & Global vision of patient / Atention also to subjective aspects * & & 3 & 2 \\
\hline & Partial vision of patient / Atention only to organic aspects & 17 & 7 & 12 \\
\hline & More interested in discussing the case than in the patient * & & & \\
\hline & More interested in the surgical act than in the patient & 7 & & 3 \\
\hline \multirow[t]{2}{*}{ Skills } & Intellectual skills / Reflexive & & & \\
\hline & Manual dexterity / Technical & 33 & 13 & 23 \\
\hline \multirow[t]{6}{*}{ Type of thinker } & Attention to detail / Meticulous / Observant & & & \\
\hline & Simplistic / No attention to details & & 3 & 2 \\
\hline & Abstract / Deals with uncertainty, ideas, hypotheses and probabilities & & & \\
\hline & Concrete / Works with the palpable, material, sensory and visual & & 7 & 3 \\
\hline & Logical & 3 & 3 & 3 \\
\hline & "Open mind" & & & \\
\hline \multirow{9}{*}{$\begin{array}{l}\text { Relationship with } \\
\text { knowledge }\end{array}$} & Scientist / Valorizes research & 3 & 3 & 3 \\
\hline & Empirical / Values experience & & 3 & 2 \\
\hline & Greater knowledge & & & \\
\hline & Less knowledge ** & 13 & & 7 \\
\hline & Reasonable knowledge & & 3 & 2 \\
\hline & More studious & & & \\
\hline & Less studious & 3 & & 2 \\
\hline & Intelligent & & 3 & 2 \\
\hline & "Mulish" & 3 & & 2 \\
\hline \multirow{18}{*}{$\begin{array}{l}\text { Type of intervention } \\
\text { and problem solving }\end{array}$} & Theoretical / Not very objective * & & & \\
\hline & Practical / Objective & 33 & 47 & 40 \\
\hline & Expectant & & & \\
\hline & Interventionist & & 7 & 3 \\
\hline & Easy going / slow to realize tasks & & & \\
\hline & Active / Dynamic in tasks & 10 & 23 & 17 \\
\hline & Does not resolve / Slow decision maker & & & \\
\hline & Resolves / Rapid decision maker & 47 & 23 & 35 \\
\hline & Knows how and when to refer & & & \\
\hline & Refers too often & & & \\
\hline & Decided / Secure/ Courageous & 17 & 23 & 20 \\
\hline & Undecisive / Insecure / Fearful & 10 & 7 & 2 \\
\hline & Precipitated / Impulsive & 20 & 10 & 15 \\
\hline & Prudent / Judicious & & 3 & 2 \\
\hline & Good sense & & 10 & 5 \\
\hline & Lack of good sense & & & \\
\hline & Less responsible for results & & & \\
\hline & Greater responsibility for results & 3 & 7 & 5 \\
\hline \multirow[t]{4}{*}{ Relationship with team } & Leadership capacity / Valorizes hierarchy & & 10 & 5 \\
\hline & Submissive / Dependent on professor & 3 & 3 & 3 \\
\hline & Demanding / Intolerant of other workers' performance & 3 & 7 & 5 \\
\hline & Flexible / Tolerant of other workers' performance & & 3 & 2 \\
\hline \multirow{4}{*}{$\begin{array}{l}\text { Relationship with } \\
\text { patient }\end{array}$} & Close / Sensitive / concerned * & 3 & & 2 \\
\hline & Distant / Insensitive / Cold ** & 30 & 7 & 18 \\
\hline & Nonaggressive & & & \\
\hline & Aggressive / Invasive & 13 & 20 & 17 \\
\hline
\end{tabular}


Table 4 - continuation

\begin{tabular}{|c|c|c|c|c|}
\hline \multirow[b]{2}{*}{ CATEGORIES } & \multirow[b]{2}{*}{ STEREOTYPE } & \multicolumn{3}{|c|}{ The Surgeon } \\
\hline & & $\begin{array}{c}\text { Gen Med } \\
(\mathrm{n}=30) \\
\%\end{array}$ & $\begin{array}{c}\text { Surgery } \\
(\mathrm{n}=30) \\
\%\end{array}$ & $\begin{array}{c}\text { Total } \\
(\mathrm{n}=30) \\
\%\end{array}$ \\
\hline \multirow{8}{*}{$\begin{array}{l}\text { Relationship with } \\
\text { profession }\end{array}$} & Does not enjoy work / Disheartened & & & \\
\hline & Enjoys work / Well-disposed $*$ & & 7 & 3 \\
\hline & Does not like stressful situations & & & \\
\hline & Enjoys stressful situations & & 10 & 5 \\
\hline & Idealist / Unselfish / Altruist & & & \\
\hline & Dissatisfied with remuneration / Stressed with work conditions $*$ & & & \\
\hline & Valorizes financial aspect & 3 & & 2 \\
\hline & Competitive / Ambitious & 10 & 3 & 7 \\
\hline \multirow{14}{*}{$\begin{array}{l}\text { Personality } \\
\text { Characteristics }\end{array}$} & Optimist & & 3 & 2 \\
\hline & Pessimist & & & \\
\hline & Modest / Less imposing & & & \\
\hline & Omnipotent / Arrogant / Prepotent & & 27 & 23 \\
\hline & Seductive & 3 & & 2 \\
\hline & Educated & & 7 & 3 \\
\hline & Rude / Bad-mannered ** & & 13 & 7 \\
\hline & Tranquil / Calm / Stable / Balanced & 7 & 3 & 5 \\
\hline & Anxious / Stressed / Nervous / Temperamental & 13 & 33 & 23 \\
\hline & Introverted / Timid & 3 & & 2 \\
\hline & Extroverted / Comunicative & 3 & & 2 \\
\hline & Good-humored & & 7 & 3 \\
\hline & Tiresome / Obstinate/ Stubborn & & & \\
\hline & Dissociated (both in and out of work environment) & & 10 & 5 \\
\hline \multirow{4}{*}{$\begin{array}{l}\text { Characteristics of } \\
\text { appearance }\end{array}$} & Short / Fat / Glutton & & & \\
\hline & Tall / Thin / large / Leptosomal & 7 & & 3 \\
\hline & Relaxed / Dresses informally & & & \\
\hline & Vain / Dresses formally & 10 & 3 & 7 \\
\hline \multirow{4}{*}{$\begin{array}{l}\text { Characteristics of } \\
\text { gender }\end{array}$} & Male sex: inherent to masculine personality & & 7 & 3 \\
\hline & Female sex: ruder and more stressed than men & & 7 & 3 \\
\hline & Female sex: hard to reconcile professional and family life & & 10 & 5 \\
\hline & Female sex: discriminated $* *$ & & 23 & 12 \\
\hline
\end{tabular}

Non-parametric: Mann Whitney U test $(\mathrm{p}<0.05)$. Note: Categories are not mutually exclusive

* Statistically significant difference between the specialties for the General Medicine group

** Statistically significant difference between the specialties for the Surgery group

rageous in relation to the problems to be resolved (20\%)

"He has to be a decisive person, he has to be more prepared for quick decisions, to keep calm and have a cool head... "Gen Med. male

- is distant, insensitive, and cold with the patient (18\%)

Only 2 residents of surgery (7\%) applied this characteristic to the surgeon, but a third of the residents of general medicine $(30 \%)$ emphasized this significantly ( $p=0.021)$ saying:

"Cold, calculating, only seeks success through surgery, impersonal with the patient and with the passing of the years becomes ever more distant from the patients' feelings... “ Gen Med. female

- is aggressive and invasive (17\%)

"The general image belongs to a person quite agitated, often aggressive in the way of working... "Sur. Female

- is dynamic in the execution of his tasks (17\%)

"Active, dynamic, he likes what he does, willing to wake up at dawn to re-operate in spite of complaining... " Sur. female

- is impetuous and impulsive when solving problems $(15 \%)$

"Shoots first and asks questions later. A man of action, the thing is to get your hands on it, few words and a lot of action. Sometimes it doesn't work out, but this is the spirit ... "Gen Med. male

- discriminates against women $(p=$ $0.005)$ in the specialty $(12 \%)$

Only the female residents of surgery $(23 \%)$ raised this issue in the surgeon's characterization, saying that:

"A woman in the surgical center is either an anesthetist or she is the surgical nurse, if a female surgeon isn't introduced she will be mistaken as something else, there is still a lot of prejudice, the jokes are macho. There are so few women... "Sur. female - has only a partial vision of the pa- 
tient, just concerned with the organic aspects (12\%)

"He leaves aside the patient's global aspect.”

Finally, $10 \%$ of the residents (all of them from the surgery group), in a significant way ( $p=0.010)$, consider the surgeon to be a complete doctor:

"We can do general treatment, no need to call someone else. As a general practitioner he is more complete. In any emergency unit, the duty chief is a surgeon... " Sur. male

Besides these differences in opinion found in the most frequent categories, other statistical differences were also verified in the surgeons' characterization, as follows:

- a doctor with lesser knowledge ( $p$ $=0.040$ )

Only some residents in the Gen Med. group (13\%) characterized the surgeon as having a lesser knowledge of medicine, affirming:

"This is prejudiced, but I don't think he has much knowledge in other areas... " Gen Med. male

- an ignorant and rude doctor ( $p=$ 0.040)

Only the residents of surgery themselves characterized the surgeon in that way $(13 \%)$ :

"Few escape this stereotype: these are extremely competent, but they also know how to behave socially, not to affront people, they know how to speak to others, to have at least a minimum of courtesy, and consideration for people... " Sur. female

\section{DISCUSSION}

There was considerable similarity in the description of a typical general practitioner and surgeon among the residents in general, regardless of the specialty they had chosen.

The general practitioner is characterized by the residents as someone with a wholistic approach with a close- ness to the patient, attending him in a global manner. His personality is thought to be easygoing and calm with a balanced and prudent way of solving problems. Also emphasized was his identification with research, the quest for knowledge, and a detailed and meticulous examination of the patient. On the other hand, he is considered theoretical and not very practical; he works with uncertainty, hypotheses and probabilities, and somewhat slowly; in short, he is characterized negatively as indecisive.

The surgeon, in turn, was described positively by the residents in general as practical and objective, purposeful and quick in making decisions, resolute and self assured, active and dynamic. Especially by the residents of that specialty, he is thought to be a complete doctor. He is also characterized as being a professional with good manual abilities and as being highly technical. He has only a partial vision of the patient in that just the organic aspects are considered. Regarding his negative traits, he is seen a doctor who is distant from the patient, aggressive, omnipotent, arrogant, and domineering. He is also anxious, stressed, impetuous, and impulsive in his actions. Finally, discrimination against women in the surgical specialty is also included in the construction of the stereotype of the specialty.

In spite of the great similarity in the characterization of the specialties, some differences of opinion were observed between the residents of the 2 specialties - whether it be for the intensity of opinions within a given category, or whether it be that the concepts were actually divergent - revealing in an interesting manner that:

- The general practitioners had little concern with defining their specialty in the "type of doctor" category for their specialty. For the surgeons this was an important category: it was significant that the general practitioner is "a necessary doctor", because he resolves most of the basic problems. Also meaningful was the concept that the surgeon is "a complete doctor", since surgery includes the general aspects.

- In relation to the "vision of the patient" category, for many residents the general medicine doctor is the one who "has a global vision of the patient", being concerned with and paying attention to subjective aspects of the patient. For some residents of surgery, significantly, the general practitioner's interest is "more in the discussion of the case, than in the patient himself". In other words, this global attention of the general practitioners represents for the surgery group more an interesting item for theoretical discussion and research than for the well being of the patient who is there to have his problem resolved.

- An essential characteristic in the definition of general practitioners by the surgery residents is that they are theoretical and not very objective in the resolution of problems. However, being an accessible doctor who is sensitive and close to the patient was the essential characteristic in the definition of a general practitioner by the residents of that specialty.

- The general practitioners themselves recognize that liking the area, but being unsatisfied with the remuneration and being stressed due to the working conditions, is something present among the doctors of their area.

- The surgeons themselves define the surgery group as "offensive and rude", but they justify that behavior, making a distinction between being in or out of the work place:

"Because of the stress, giving an order ends up being gruff, it's under- 
standable, it's during surgery, but once outside you are calm... " Sur. male

- Only the general practitioners attribute the surgeon with a lesser knowledge of medicine.

- Only surgeons use gender attributes in their definition to characterize the "typical doctor" of their specialty.

It is interesting to observe that analysis of these stereotypes brings to mind that the qualities attributed to physicians and surgeons in the beginnings of medicine (so-called in Brazil "barber surgeons") are still used to characterize them in the present, especially considering the degree of knowledge attributed to surgeons (by general practitioners, of course. . .). For instance, in the following answer:

“This is prejudiced, but I don't think the surgeon has much knowledge in other areas. . . " Gen Med. male
The perceptions of the "cultivated mind of the physician" said of general practitioners, and the "courage to act without knowledge", said of surgeons in the past, persist to the present.

The duality between the thinker and the mechanic, the scientist and the empiricist, working with ideas and working with the tangible, despite the extraordinary evolution of science within medicine, continues regarding the professional stereotypes of each area.

On the other hand, social valorization and the power to resolve problems - aspects that were not part of a surgeon's attributes in the past - are now important factors in the reason for choosing this area and essential components in the characterization of this specialty.

Surgeons are guaranteed today, with certainty, their self respect (many considering themselves "a complete doctor"), the respect of colleagues (in spite of the stereotypes and rivalry), and principally the respect from the patient: "It is God in the sky and the doctor on earth. ..'

These changes in the specialties have reinforced that, although the stereotypes present some advantages in facilitating communication, they can, in their incomplete, rigid, and prejudiced form, produce misconceptions that impede a choice consistent with the current reality of the various professions.

\section{ACKNOWLEDGEMENTS}

The author thanks all the residents that participated in this study for their collaboration and enthusiasm with the research objectives.

\section{RESUMO}

BELLODI PL - O clínico e o cirurgião: estereótipos e especialidades médicas. Rev. Hosp. Clín. Fac. Med. S. Paulo 59(1):15-24, 2004.

OBJETIVOS: Investigar e caracterizar entre residentes brasileiros os estereótipos profissionais associados ao médico clínico e ao cirurgião.

METODOLOGIA: uma amostra randomizada de residentes dos programas de Clínica Médica e Cirurgia foi entrevistada e suas representações a respeito das duas áreas caracterizadas e comparadas.

RESULTADOS: O clínico foi representado, pelos residentes em geral, principalmente como um médico sensível, próximo e preocupado com o paciente $(45 \%)$; calmo, tranqüilo e equilibrado $(27 \%)$; com habilidades intelectuais $(25 \%)$; detalhista e meticuloso (23\%); pouco resolutivo e demorado para tomar decisões $(22 \%)$; trabalha mais com probabilidades e hipóteses $(20 \%)$. Já o cirurgião foi caracterizado como um médico prático e objetivo (40\%); resolutivo e rápido (35\%); técnico com habilidades manuais $(23 \%)$; onipotente, arrogante e prepotente $(23 \%)$; ansioso, estressado, nervoso, temperamental (23\%), mas decidido, seguro e corajoso (20\%). Somente os residentes da clínica atribuem ao cirurgião um conhecimento menor da medicina e apenas os cirurgiões atribuem características de gênero à própria especialidade.
CONCLUSÃO: Houve muita semelhança na descrição do médico clínico e do médico cirurgião entre os residentes em geral, independentemente da especialidade a qual pertenciam. Interessante observar que, ainda hoje, os estereótipos do clínico e do cirurgião assemelham-se bastante, apesar das transformações ocorridas ao longo do tempo, à tradição dos antigos físicos (especialmente quanto à valorização da mente) e dos cirurgiões-barbeiros (associados a um menor conhecimento e à realização de procedimentos arriscados) na história da medicina.

DESCRITORES: Especialidades, médicas. Educação, médica. Estereótipos, Brasil. 


\section{REFERENCES}

1. Moscovici S. A representação social da psicanálise. Rio de Janeiro, Zahar, 1978.

2. Anderson RBW. Choosing a medical specialty: a critique of literature in the light of "curious findings". J Hlth Soc Behav 1975; 16: 152-162.

3. Geertsma RH, Grinols DR. Specialty choice in medicine. J Med Educ 1972; 47: 509-517.

4. Bruhn JG, Parsons AO. Medical student attitudes toward four medical specialties. J Med Educ 1964; 39: 40-49.

5. Martin FM, Mayo PR, Mcpherson, FM. Professional stereotypes of first-year medical students. Br J Med Educ 1967; 1: 368373 .

6. Zimny GH, Thale TR. Specialty choice and attitudes toward medical specialties. Soc Sci Med 1970; 4: 257-264.

7. Becker HS, Geer B, Hughes EC et al. Boys in White. Chicago, University of Chicago Press, 1961.

8. Furnham A. Career attitudes of pre general medical students to the medical specialties. Med Educ 1986; 20: 286-300.
9. Otis GD, Weiss JR. Patterns of medical career preference. J Med Educ 1973; 48: 1116-1123.

10. Coombs RH, Fawzy FI, Daniels ML. Surgeons' personalities: the influence of medical school. Med Educ 1993; 27: 337-343.

11. Linn BS, Zeppa R. Does surgery attract students who are more resistant to stress? Ann Surg 1984; 200: 638-643.

12. Wright MR. Self-perception of the elective surgeon and some patient perception correlates. Arch Otoryn 1980; 106: 40605 .

13. Zimet CN, Held ML. The development of views of specialties during four years of medical school. J Med Educ 1975; 50: 157-166.

14. Cruz EMTN. A escolha da especialidade em medicina. Campinas, 1976 (Tese - Faculdade de Ciências Médicas, UNICAMP)

15. Nunes ED. Medicina como profissão: contribuição ao estudo da escolha ocupacional entre estudantes de Medicina. Rev Bras Educ Méd 1979; 3: 47-60.

16. Linn BS, Zeppa R. Does surgery attract students who are more resistant to stress? Ann Surg 1984; 200: 638-43. 